logos_i_ethos_2020_1_(53), s. 163-178

DOI: http://dx.doi.org/10.15633/lie.3694

Sebastian Gałecki

https://orcid.org/0000-0003-2728-0447

Uniwersytet Humanistyczno-Przyrodniczy im. Jana Długosza w Częstochowie

\title{
Rozumowanie moralne - norma czy wyjątek?
}

\section{Spór o rolę rozumowania w moralności}

Na przełomie lat osiemdziesiątych i dziewięćdziesiątych odbył się ciekawy - choć tylko papiero-

Sebastian Gałecki - dr filozofii, stypendysta Duquesne University oraz Notre Dame University, adiunkt na UJD w Częstochowie, główne obszary zainteresowań: etyka i bioetyka, historia idei, filozofia społeczna, relacja nauka-religia.

wy (dziś powiedzielibyśmy: wirtualny) - spór pomiędzy Alasdairem MacIntyre’em i Johnem Finnisem. Choć obaj reprezentują współczesną, anglosaską filozofię i etykę chrześcijańską, to poróżniła ich kwestia rozumowania praktycznego, czyli posługiwania się rozumem w sferze moralności. Status questionis brzmiał: czy rozumowanie praktyczne stanowi normę - korzystamy z niego w przypadku każdego aktu moralnego czy też posługujemy się nim tylko w wyjątkowych, niestandardowych sytuacjach.

W Czyja sprawiedliwość? Jaka racjonalność? znajdziemy jasno wyrażoną opinię MacIntyre’a: „Wszelkie rozumowanie praktyczne zaczyna się od pytania: «Co mam robić?». Pytanie to ma sens tylko wtedy, gdy podmiotowi sam nasuwa się lub został mu przedstawiony powód, by zrobić coś innego niż to, co zwykle by uczynił w normalnej sytuacji"'. A zatem rozumowanie praktyczne stanowi nie regułę, lecz wyjątek - w normalnej sytuacji podmiot działa w zgodzie ze „strukturami normalności”, 
czyli tak, jak został nauczony. Owe struktury normalności to nic innego, jak pewne standardy działania: czymś oczywistym jest, że widząc rannego, lekarz pogotowia ratunkowego zatrzyma się, by udzielić mu pomocy. „Działanie w zgodzie z tymi strukturami nie wymaga podawania lub posiadania powodów do działania" ${ }^{2}$, podmiot moralny postępuje niemal w sposób automatyczny, zgodnie z ugruntowanymi w danej wspólnocie przekonaniami i normami. W typowej sytuacji nikt go nie zapyta o powód, rację postępowania (reason to action) w taki właśnie sposób - lekarz pogotowia nie będzie musiał ani zastanawiać się nad swoim działaniem, ani obawiać, że będzie musiał stanąć przed komisją dyscyplinarną.

Co jednak w przypadku „pewnych specyficznych okoliczności, w których te struktury zostały zakwestionowane"? Na przykład: karetka jedzie do wypadku masowego i widząc osobę leżącą na poboczu niedaleko szpitala lekarz wydaje polecenie, by się nie zatrzymywać. Zdaniem MacIntyre’a będzie to już sytuacja poza „strukturami normalności” i lekarz musi nie tylko posiadać adekwatną „rację do działania” w ten właśnie sposób, ale także musi być gotowy do ewentualnego podania tych powodów swoim przełożonym, a nawet prokuratorowi lub sędziemu. O ile mogą się bowiem zdarzyć sytuacje wyjątkowe, wymagające nietypowej decyzji lub wykonania czynu innego, niż wynikałby z uznanej w danej wspólnocie „struktury normalności”, o tyle ekstraordynaryjność tej sytuacji zakłada również nadzwyczajną staranność w namyśle moralnym. W sytuacjach niezgodnych ze „strukturami normalności” jesteśmy bowiem zobowiązani do zdobycia odpowiednich racji do działania, które - $\mathrm{w}$ razie konieczności - będziemy potrafili przedstawić członkom naszej wspólnoty moralnej.

Dlatego MacIntyre stoi na stanowisku, że rozumność praktyczna „uruchamiana” jest w sytuacjach wyjątkowych, kiedy w danej społeczności „struktury normalności” są niewystarczająco obowiązujące. Stanowi ona niejako „spadochron zapasowy”, uruchamiany w sytuacjach ekstraordynaryjnych. Dlatego tak istotne są dobrze funkcjonujące struktury

2 A. MacIntyre, Czyja sprawiedliwość? Jaka racjonalność?, dz. cyt., s. 75. 
normalności, dzięki którym „zbędny staje się wymóg ciągłego uzasadniania obecnego lub przyszłego działania”, które stanowi - zdaniem autora tych słów - „nieznośny ciężar” ${ }^{3}$.

Całkowicie przeciwne stanowisko zajął John Finnis, wprost wskazując Alasdaira MacIntyre’a i Marka Tushneta jako swoich oponentów ${ }^{4}$. Jego zdaniem opinia o ograniczonej stosowalności rozumowania praktycznego jest zwyczajnie błędna. Z natury samego „czwartego porządku” rzeczywistości (dotyczącego ludzkich decyzji i działań) wynika „to, że podejmujemy rozumny namysł i dokonujemy rozumnych wyborów"5 - nie można mówić o moralności poza kontekstem racjonalnego i świadomego podejmowania decyzji. Rozumowanie praktyczne stanowi zatem warunek sine qua non moralności.

Finnis uważa, że rozumowanie praktyczne potrzebne jest nie tylko w sytuacjach wyjątkowych („kiedy trzeba podjąć trudną decyzję”), ale także w prostych przypadkach (easy case) lub w przypadkach hipotetycznych (game-theoretical situations). Wynika to z założeń antyutylitarystycznych (vel antykonsekwencjalistycznych): dobry wybór nie jest tożsamy z wyborem najlepszym. Czasami musimy zaakceptować negatywne konsekwencje naszych decyzji („efekty uboczne”), ale mamy obowiązek wybrać nie to zachowanie, które jest proporcjonalnie najlepsze (np. „mniejsze zło”), lecz zachowanie dobre, szanujące fundamentalne dobra, takie jak życie, prawda, przyjaźń etc. Dlatego nawet w sytuacji, gdy mamy przed sobą tylko jedną możliwość wyboru (easy case) rozumowanie praktyczne również jest prowadzone, by ocenić tę propozycję działania w świetle obiektywnych kryteriów prawa naturalnego.

Choć może „łatwość łatwych przypadków powoduje mniejsze zainteresowanie prawników”, to „budzi najwyższe zainteresowanie i ma

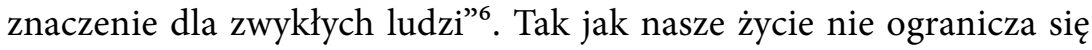

3 A. MacIntyre, Czyja sprawiedliwość? Jaka racjonalność?, dz. cyt., s. 75.

4 J. Finnis, Practical Reasoning in Law: Some Clarifications, w: J. Finnis, Philosophy of Law. Collected Essays: Volume IV, New York 2011, s. 371-372.

5 J. Finnis, Prawo naturalne i uprawnienia naturalne, tłum. K. Lossman, Warszawa 2002, s. 155.

6 J. Finnis, Practical Reasoning in Law: Some Clarifications, dz. cyt., s. 272. 
do trudnych dylematów w rodzaju „dylematu wagonika"7 tak też nasza rozumność ma zastosowanie również w codziennych sprawach, błahych decyzjach i „prostych sprawach”. Tam, gdzie jest moralność, tam też mamy do czynienia z wolnością i rozumnością, a głównym wyrazem racjonalności człowieka jest jego namysł w sprawach moralnych, bez względu na rangę decyzji i stopień skomplikowania czynu.

Który z nich ma rację? MacIntyre - rezerwujący zastosowanie rozumowania moralnego do trudnych sytuacji, wykraczających poza ,strukturę normalności” - czy Finnis, uznający namysł moralny za warunek konieczny każdego aktu osoby ludzkiej? Zanim zajmę własne stanowisko $\mathrm{w}$ tym istotnym sporze, postaram się nakreślić szersze tło. Nasi bohaterowie pomimo różnienia się $\mathrm{w}$ sprawie roli rozumowania praktycznego, zgadzają się co do jego dwoistej natury. Zrozumienie tej tezy czyni odpowiedź na pytanie o rolę rozumowania moralnego dość prostą.

\section{Dwa rodzaje rozumowania}

Zarówno MacIntyre, jak i Finnis podkreślają, że nie istnieje jeden sposób rozumowania, lecz dwa. Każdy z nich podchodzi do tego rozróżnienia we własny, oryginalny sposób - także stosując odmienną terminologię - lecz ich wnioski w żaden sposób nie są ze sobą sprzeczne.

\subsection{Alasdair MacIntyre: pierwszoosobowy i trzecioosobowy punkt widzenia}

Zacznijmy od MacIntyre’a, u którego podział na dwa rozumowania jest prostą konsekwencją innych dualizmów. Jedną z głównych tez jego Dziedzictwa cnoty jest odróżnienie od siebie dóbr wewnętrznych dla danej praktyki od dóbr wobec niej zewnętrznych ${ }^{8}$. Praktyką w znaczeniu

7 P. Foot, The Problem of Abortion and the Doctrine of the Double Effect, w: P. Foot, Virtues and Vices and Other Essays in Moral Philosophy, Oxford 2002, s. 23.

8 Zob. A. MacIntyre, Dziedzictwo cnoty. Studium z teorii moralności, tłum. A. Chmielewski, Warszawa 1996, s. 339-340. 
odnowionej etyki cnót będzie np. gra w szachy. Wyobraźmy sobie dziecko, które próbujemy nauczyć gry w szachy. Najłatwiej będzie to zrobić „przekupując” je czymś, co lubi - np. czekoladą. Dopiero wówczas możemy mieć nadzieję, że zgodzi się poświęcać swój cenny czas, który mogłoby spożytkować na coś przyjemnego - np. na grę w piłkę z kolega$\mathrm{mi}$ - na nudne i żmudne uczenie się zasad oraz taktyki gry w szachy. Czekolada będzie w tym znaczeniu dobrem zewnętrznym wobec praktyki gry w szachy. Ale naszym celem jest przecież to, by dziecko odkryło wartość samej gry, by za kilka tygodni lub miesięcy chciało rozgrywać partie bez dodatkowej motywacji w postaci słodyczy. Innymi słowy: by jego celem nie było dobro zewnętrzne (czekolada), lecz dobro wewnętrzne szachów, jakim jest umiejętność logicznego myślenia, wyobraźnia strategiczna lub wola walki. Prawdziwego szachistę można poznać właśnie po tym, że gra dla osiągnięcia owych dóbr wewnętrznych.

Zakładając okulary etyki klasycznej, łatwo można dostrzec, że dobra zewnętrzne odpowiadają temu, co np. Ambroży z Mediolanu i Tomasz z Akwinu' nazywali bonum utile i bonum delectabile (dobro, które jest środkiem do celu lub które cenimy ze względu na przyjemność, jakiej nam dostarcza), podczas gdy dobra wewnętrzne są tożsame z bonum honestum, dobrem samym w sobie, prawdziwym celem działań moralnie słusznych ${ }^{10}$. We wspomnianej już książce Czyja sprawiedliwość? Jaka racjonalność? MacIntyre wprowadza paralelne rozróżnienie, łącząc dobra zewnętrzne $\mathrm{z}$ dobrami efektywności (goods of effectiveness), natomiast dobra wewnętrzne z dobrami doskonałości (good of excellence). Dobra efektywności nie tylko nie pokrywają się z dobrami doskonałości, lecz czasami mogą wręcz uniemożliwić ich zdobycie. Pomyślmy o sportowcu, który przygotowuje się do olimpiady w pływaniu na 100 metrów stylem dowolnym. Dobrem efektywności - zewnętrznym wobec samego sportu - będzie zwyciężenie na olimpiadzie, nagroda finansowa, sława etc.

9 Św. Ambroży z Mediolanu, Obowiązki duchownych, tłum. K. Abgarowicz, Warszawa 1967, s. 29; Tomasz z Akwinu, Traktat o Bogu, tłum. G. Kurylewicz i inni, Kraków 1999, s. 80-81.

10 Por. A. Chmielewski, MacIntyre a współczesna filozofia polityczna, w: A. MacIntyre, Czyja sprawiedliwość? Jaka racjonalność?, dz. cyt., s. 23. 
Skutecznym sposobem na osiągnięcie tego dobra będzie wspomaganie treningu nielegalnymi środkami dopingującymi. Jednocześnie doping uniemożliwi zawodnikowi osiągnięcie dobra doskonałości, jakim jest kondycja fizyczna i zostanie - rzeczywiście, a nie tylko w oficjalnym raporcie z igrzysk - najszybszym pływakiem na świecie. Na szczęście, najczęściej dobra efektywności i doskonałości się uzupełniają i wzajemnie wspomagają.

Dlaczego zwracam na to uwagę? Ponieważ w inny sposób dążymy do dóbr zewnętrznych/efektywności, a inaczej do dóbr wewnętrznych/ doskonałości. Skoro istnieje nie jedna kategoria dobra, lecz dwie, to należy uznać, że istnieją także dwa rodzaje rozumności praktycznej, według których wartościujemy te dobra i szukamy środków do ich zdobycia. Co jeszcze ważniejsze, „dobry powód do działania w opinii tych, którzy za kontekst rozumowania praktycznego rozumieją formy aktywności zmierzające do dóbr doskonałości, jest bardzo odmienny od tego, co za dobry powód do działania uznają ci, dla których" celem jest osiągnięcie dóbr efektywności ${ }^{11}$. Ktoś, kto chce zdobyć złoty medal na olimpiadzie, może np. zaakceptować doping jako skuteczniejszy i pewniejszy sposób osiągnięcia tego celu, podczas gdy ktoś, kto trenuje, by stać się wybitnym pływakiem, będzie takie środki uważał za całkowicie sprzeczne $\mathrm{z}$ duchem sportu. $\mathrm{Z}$ tego samego powodu pierwsza osoba będzie pogardzała kolegą, który nie chce stosować dopingu, a druga będzie potępiała współzawodników uciekających się do „drogi na skróty”.

Jeśli uczestniczymy w danej praktyce ze względu na jej dobra wewnętrzne, dobra doskonałości (np. rozwinięcie umiejętności logicznego analizowania, właściwego grze w szachy), nieco inaczej będziemy rozumować niż wtedy, gdy zastanawiamy się nad zdobyciem jakiegoś dobra zewnętrznego wobec praktyki, dobra efektywności (np. nagrody pieniężnej za wygranie lokalnego turnieju szachowego). Pierwszy sposób rozumowania, którego celem jest odkrycie tego, co uczyni mnie lepszym człowiekiem i - w tym przykładzie - lepszym szachistą, będzie odmienne niż rozumowanie w celu jak najbardziej skutecznego działania,

11 A. MacIntyre, Czyja sprawiedliwość? Jaka racjonalność?, dz. cyt., s. 95. 
by osiągnąć jakieś dobro zewnętrzne (sukces, sławę, majątek etc.). To, w jaki sposób definiuje „,dobro dla mnie”, ma bezpośredni wpływ na to, w jaki sposób namyślam się nad osiągnięciem go: „moje rozumowanie praktyczne wychodzi nie od jakiegoś dobra, cóż dopiero dobra, o którym nie mam jeszcze pojęcia, lecz ode mnie samego jako dążącego do czegoś pod wpływem potrzeby lub pragnienia, których realizacja lub zaspokojenie przyniesie mi zadowolenie" ${ }^{12}$.

Jeszcze lepiej tę dwoistość racjonalności widać w analizie ludzkiego poznania, jaka została przeprowadzona w książce poświęconej filozofii Edyty Stein ${ }^{13}$. MacIntyre wskazuje tam (za Stein i Husserlem), że wiedza, którą zdobywamy, może być dwojaka. Nasze pragnienia, intencje, „jaźń" zdobywamy niejako z pierwszoosobowego punktu widzenia (first person standpoint), ale istnieje także wiedza - jak się wydaje znacznie szersza, obejmująca całą naukę przyrodniczą - która dostępna jest z trzeciosobowego punktu widzenia (third person standpoint). Co ciekawe, duża część zjawisk (akty mentalne i doświadczenia zmysłowe) może być przedmiotem zarówno osobistego i bezpośredniego doświadczenia, które odbieramy w pierwszej osobie, jak i niezaangażowanego rozumowania z perspektywy zewnętrznego, trzecioosobowego obserwatora.

MacIntyre nazywa to „podwójnym życiem” tych doświadczeń i doznań: istnieją zarówno jako moje własne, nieprzekazywalne odczucia, jak i jako przedmiot ewentualnej analizy rozumowej niejako „z zewnątrz” (nawet jeśli to ja sam analizuję swoje własne doświadczenia). Te dwie perspektywy różnią się nie tylko przedmiotem, lecz przede wszystkim dostępnością: w pierwszoosobowym punkcie widzenia ja i tylko ja mam narzędzia pozwalające mi ocenić przedmiot mojego badania. W efekcie rozumowanie przybiera postać jednego $\mathrm{z}$ dwóch (choć czasami obu równocześnie) sposobów rozumowania: wewnętrznego i bezpośredniego lub zewnętrznego i niezaangażowanego. W moralności chodzi zatem $\mathrm{o}$ to, by tę wiedzę obiektywną, związaną z trzecioosobowym punktem

12 A. MacIntyre, Czyja sprawiedliwość? Jaka racjonalność?, dz. cyt.,- s. 97.

13 A. MacIntyre, Edyta Stein. Prolog filozoficzny 1913-1922, tłum. J. Guerrero van der Meijden, Kraków 2019, s. 144-148. 
widzenia, uczynić swoją własną, osobistą perspektywą. Idealna jest ta sytuacja, gdy pierwszoosobowy punkt widzenia podmiotu moralnego jest otwarty na - i poinformowany przez obserwacje - argumenty i sądy trzecioosobowe ${ }^{14}$.

\subsection{John Finnis: wewnętrzny i zewnętrzny punkt widzenia}

Analogiczne rozróżnienie - na „pierwszoosobowy” i „trzecioosobowy punkt widzenia” (first-person and third-person viewpoints) - znajdziemy także u Finnisa, choć on zaczerpnął je nie od fenomenologów (jak MacIntyre), lecz od analitycznych filozofów prawa ${ }^{15}$. Te dwie perspektywy Australijczyk nazywa „asymetrycznymi”, ponieważ nie stanowią alternatywnych ujęć problemu, lecz dwa prawdziwie niezależne paradygmaty rozumowania. $\mathrm{O}$ ile bowiem trzecioosobowy punkt widzenia zmierza do ustalenia faktów dotyczących innych osób, ich poglądów i działań, o tyle pierwszoosobowy punkt widzenia poszukuje nie faktów, lecz racji do działania. Dlatego ową trzecioosobową perspektywę nazywa rozumowaniem teoretycznym, podczas gdy perspektywa pierwszoosobowa związana jest z rozumnością praktyczną - praktyczną dlatego, że jest rozumowaniem dotyczącym wybierania i działania, a zatem jej przedmiotem jest m.in. moralność ${ }^{16}$.

Ten typ rozumowania i rozumności Finnis nazywa także „wewnętrznym punktem widzenia” (internal viewpoint), to znaczy takim sposobem myślenia, który zasady, normy i reguły traktuje jako racje do działania (lub niedziałania), a nie tylko jako fakt, opinię czy prognozę - źródło wiedzy teoretycznej ${ }^{17}$. Albo innymi słowy: „Z «wewnętrznego» punktu

14 Zob. A. MacIntyre, Ethics in the Conflicts of Modernity. An Essay on Desire, Practical Reasoning, and Narrative, Cambridge 2016, s. 161-162.

15 Zob. J. Finnis, On Hart's Ways: Law as Reason and as Fact, w: J. Finnis, Philosophy of Law, dz. cyt., s. 235-236; 255-256.

16 Zob. J. Finnis, Commensuration and Public Reason, w: J. Finnis, Reason in Action. Collected Essays: Volume I, New York 2011, s. 236; J. Finnis, Prawo naturalne i uprawnienia naturalne, dz. cyt., s. 18.

Zob. J. Finnis, A Grand Tour of Legal Theory, w: J. Finnis, Philosophy of Law, dz. cyt., s. 119. 
widzenia racje są rozumiane jako racje do działania" (reasons are understood as reasons $)^{18}$, a nie jedynie jako zjawiska psychologiczne. „Wewnętrzny” od „zewnętrznego” punktu widzenia odróżnia się przede wszystkim cechą, którą Finnis nazywa „przezroczystością" (transparency). Oznacza to, że wewnętrzny punkt widzenia jest niewrażliwy, „przezroczysty” na to, kto daną tezę wypowiada: „twierdzenia, takie jak «myślę, że p» są przezroczyste dla twierdzeń «tak jest w przypadku p» lub po prostu: "p». Tak więc «myślę» w twierdzeniach pierwszego rodzaju jest przezroczyste dla prawdziwego przedmiotu twierdzenia: moje myślenie wcale nie jest częścią tego przedmiotu"19. Pierwszoosobowy punkt widzenia nie bierze pod uwagę tego, kto stwierdza dany fakt, lecz jedynie to, że dany fakt zaistniał. Przezroczystość wewnętrznego punktu widzenia można porównać z grami komputerowymi zwanymi potocznie FPS (first-person shooter), w której postać, w którą się wcielamy, nie jest widoczna - obserwujemy rzeczywistość jej oczami. Zewnętrzny punkt widzenia jest $z$ kolei wrażliwy na to, co ktoś twierdzi - inaczej będziemy traktowali wypowiedź na tematy ekonomiczne noblisty z tej dziedziny, a inaczej zupełnego amatora $\mathrm{w}$ tym obszarze.

Jednak kluczowa różnica między rozumowaniem pierwszoosobowym/wewnętrznym a trzecioosobowym/zewnętrznym - i tutaj Finnis jest całkowicie zgodny z MacIntyreem - polega na odmienności celu. O ile jednak MacIntyre wskazuje na odmienność dóbr (pierwsze prowadzi przede wszystkim do dóbr wewnętrznych i doskonalących osobę, podczas gdy drugie ułatwia zdobycie dóbr zewnętrznych, zwiększając skuteczność działania), o tyle Finnis odwołuje się do dwóch kategorii prawdy i wiedzy. Nazywa je rozmaicie: prawdą niepraktyczną (non-practical) i prawdą praktyczną (practical truth); prawdą wiedzy teoretycznej (truth of theoretical knowledge) i prawdą wiedzy praktycznej (truth of practical knowledge), „wiedzą-tego-co-jest” (Is-knowledge) i „wiedzą-dotyczącą-powinności" (Ought-knowledge) lub wglądem niepraktycznym

\footnotetext{
18 J. Finnis, Human Rights and Their Enforcement, w: J. Finnis, Human Rights and Common Good. Collected Essays: Volume III, New York 2011, s. 25.

19 J. Finnis, Fundamentals of Ethics, Washington 1983, s. 71.
} 
(non-practical insight) i wglądem praktycznym (practical insight $)^{20}$. Bez względu na nazwę, chodzi o to, że skutkiem rozumowania z perspektywy pierwszoosobowej i wewnętrznej jest wiedza i prawda praktyczna czyli znajomość tego, co powinienem zrobić („to ma być uczynione”), racja do działania. Natomiast rozumowanie z perspektywy teoretycznej (trzecioosobowe, zewnętrzne) prowadzi do zdobycia wiedzy i prawdy teoretycznej, dotyczących tego, co jest („A jest B”), faktów. Mamy zatem do czynienia $\mathrm{z}$ dwoma rodzajami rozumowania, które prowadzą do dwóch odrębnych rodzajów dobra, prawdy i wiedzy - jeśli chcę odkryć, co jest dobrem, które powinienem teraz osiągnąć, muszę skorzystać $\mathrm{z}$ rozumowania wewnętrznego (pierwszoosobowego); jeśli interesuje mnie tylko to, co jest dobrem in abstracto, posługuję się rozumowaniem zewnętrznym (trzecioosobowym) ${ }^{21}$.

\subsection{John Henry Newman: rozumowanie implikatywne i eksplikatywne}

Do tego dwugłosu MacIntyre-Finnis chciałbym dodać opinię jeszcze jednego, ostatnimi laty szczególnie odkrywanego anglosaskiego filozofa chrześcijańskiego, Johna Henry’ego Newmana, który najlepiej - moim zdaniem - opisał dwoistość rozumowania ludzkiego. W swoich głośnych Kazaniach uniwersyteckich wprowadził on podział na rozumowanie implikatywne i eksplikatywne ${ }^{22}$. To rozróżnienie także związane jest $\mathrm{z}$ odmiennością celów poznania. Brytyjczyk wprowadza wyraźną granicę pomiędzy rzeczywistością (real) a opisaniem jej przy pomocy pojęć i idei (notion). W inny sposób zdobywamy wiedzę na temat rzeczy,

20 Zob. J. Finnis, G. Grisez, J. Boyle, Practical Principles, Moral Truth, and Ultimate Ends, „American Journal of Jurisprudence” 32 (1987), s. 115-116; J. Finnis, Introduction, w: J. Finnis, Reason in Action, dz. cyt., s. 8; J. Finnis, Practical Reason's Foundations, w: J. Finnis, Reason in Action, dz. cyt., s. 39.

21 Zob. J. Finnis, Introduction, dz. cyt., s. 3.

22 Zob. J. H. Newman, Rozum implikatywny i rozum eksplikatywny, w: J. H. Newman, Kazania uniwersyteckie. Piętnaście kazań wygtoszonych przed Uniwersytetem Oksfordzkim między 1826 a 1843 rokiem, tłum. P. Kostyło, Kraków 2000, s. 234-256. 
a inaczej osiągamy ich zrozumienie, adekwatny opis zjawisk. Do obszaru real w sposób szczególny należy moralność i wiara (podczas gdy etyka i teologia stanowią owoc rozumowania eksplikatywnego), ponieważ rozum w sferze implikatywnej pojmuje powinność (tutaj całkowita zgoda Newmana z Finnisem), a jako eksplikatywny - prawdę ${ }^{23}$.

Nie chodzi zatem o dwie osobne władze czy zdolności, lecz o dwa niezależne procesy rozumowania, różniące się właściwym sobie przedmiotem oraz hierarchicznie uporządkowane ${ }^{24}$. Rozumowanie implikatywne dotyczy bezpośrednio rzeczywistości i ma charakter pierwotny jego celem jest odkrycie, jak rzeczy faktycznie się mają, by zdobyć racje do działania ( to have a reason), często w sposób całkowicie nieświadomy, ukryty, podczas gdy rozumowanie eksplikatywne stanowi analizę procesu rozumowania implikatywnego, analizując idee i pojęcia, a nie na same rzeczy - jego celem jest uzasadnienie rezultatów rozumowania ukrytego, to znaczy: odkrycie i ujawnienie racji (to give a reason) ${ }^{25}$. To bardzo ważne rozróżnienie: czymś innym jest umiejętność poprawnego rozumowania i podejmowania właściwych decyzji (have a reason), a czymś innym jest zdolność do wyrażenia ich lub poprawnego argumentowania na ich rzecz (give a reason) ${ }^{26}$.

W inny sposób rozumuję, by odkryć, co powinienem zrobić, a inaczej rozumuję, by przekonać kogoś innego, że podjąłem właściwą decyzję ${ }^{27}$. Te dwa sposoby rozumowania są od siebie odrębne i niezależne w tym sensie, że rozumowanie eksplikatywne niczego nie zmienia w dokonanym procesie implikatywnym, a jedynie czyni uprzednio odkryte racje

23 Zob. J. H. Newman, Intellect, the Instrument of Religious Training, w: J. H. Newman, Sermons Preached on Various Occasions, London 1908, s. 5.

24 Por. S. Gałecki, Spór o sumienie. Źródła i konsekwencje etyki Johna Henry’ego Newmana, Kraków 2012, s. 169-218.

${ }^{25}$ J. H. Newman, Rozum implikatywny i rozum eksplikatywny, dz. cyt., s. 240.

26 J. H. Newman, Natura wiary w relacji do rozumu, w: J. H. Newman, Kazania uniwersyteckie, dz. cyt., s. 202.

$27 \mathrm{Z}$ całą pewnością warto byłoby dokonać analizy porównawczej pomiędzy Newmanowskim rozróżnieniem na rozumowanie implikatywne i eksplikatywne a sformułowanym sto lat później rozróżnieniem Reichenbacha na kontekst odkrycia i kontekst uzasadnienia. Zob. H. Reichenbach, Trzy zadania epistemologii, tłum. W. Sady, „Studia Filozoficzne” 7-8 (1989) 284-285, s. 205-212. 
intersubiektywnymi i zrozumiałymi dla zewnętrznych obserwatorów (MacIntyre i Finnis powiedzieliby: dla patrzących z perspektywy trzecioosobowej). Rozumowanie implikatywne jest bezpośrednio związane $\mathrm{z}$ moralnością i stanowi podstawę odpowiedzi na pytanie, co jest dobrem, do którego w tej sytuacji, w której się znalazłem, mogę i powinienem dążyć. Rozumowanie eksplikatywne może - ale nie musi! mu towarzyszyć, rozpoznając punkt wyjścia (np. pierwsze zasady lub dobra podstawowe) i drogi, którymi podążało w poszukiwaniu swojej odpowiedzi. Ma zatem charakter retrospektywny, posługując się przede wszystkim narzędziami poszczególnych nauk, głównie logiki ${ }^{28}$.

\section{Rozstrzygnięcie sporu}

Stwierdzam zatem, że uznanie dwóch rodzajów, modi rozumowania jednego ściśle związanego z moralnością, a drugiego bardziej z etyką jako teorią moralności - stanowi bezsporne założenie wszystkich trzech przedstawicieli współczesnej anglosaskiej etyki chrześcijańskiej. Każdy $\mathrm{z}$ nich zgadza się z tym stwierdzeniem, choć nieco inaczej te dwa procesy rozumowania nazywa (pierwszo- i trzecioosobowa perspektywa badawcza, wewnętrzny i zewnętrzny punkt widzenia, rozumowanie implikatywne i eksplikatywne).

Przyjęcie tezy o podwójności rozumowania pozwala także pokonać spór między MacIntyrem a Finnisem co do zwyczajności lub nadzwyczajności rozumowania moralnego. Fundamentalna z perspektywy Alasdaira MacIntyre’a „struktura normalności” pozwala zrezygnować $\mathrm{z}$ rozumowania eksplikatywnego, trzeciosobowego i zewnętrznego (czyli z podawania racji działania - to give a reason), ale nigdy $\mathrm{z}$ implikatywnego, wewnętrznego i pierwszoosobowego (poszukującego racji działania - to have a reason).

W tym przypadku uznaję stanowisko Finnisa: rozumowanie praktyczne (czyli znajdujące swój finał w działaniu) jest kluczowym

28 Zob. J. H. Newman, Przedmowa do wydania trzeciego, w: J. H. Newman, Kazania uniwersyteckie, dz. cyt., s. 20. 
elementem każdego ludzkiego poszukiwania odpowiedzi na pytanie o to, co w danej sytuacji jest dobre i słuszne. Nie stanowi zatem wyjątku, lecz regułę. Jednocześnie zgadzam się z MacIntyrem co do tego, że istnieje zasadnicza różnica pomiędzy sytuacją zgodną ze „strukturą normalności", czyli taką, w której oceniamy jakiś czyn lub sami działamy zgodnie z uznanymi w danej społeczności normami, a oceną lub działaniem z tą strukturą sprzecznymi. „Struktura normalności” niejako stanowi sama w sobie wyrażenie racji do działania, zwalniając podmiot z konieczności poszukiwania trzecioosobowej perspektywy, intersubiektywnych argumentów. Niemniej, nie zwalnia ona ze zdobycia racji do działania, bez których postępowanie zawsze będzie nieracjonalne, a przez to - będzie zaprzeczało rozumnej naturze człowieka.

Mógłby ktoś powiedzieć, że nie powinien nas dziś interesować spór sprzed kilku dekad. Ale przecież jest on kluczowy zwłaszcza teraz, kiedy tracimy - z powodu globalizacji i pluralizmu kulturowego - działające dotychczas „struktury normalności”. Coraz częściej będziemy spotykali się z pytaniem „dlaczego tak postąpiłeś?” lub „dlaczego wybrałeś raczej tę wartość niż inną?". Uznanie - jak chciałby MacIntyre - że w przypadku większości czynów nasza decyzja posiada przywilej oczywistości, wydaje mi się całkowicie nieuprawnione w świecie, w którym żyjemy. Każde działanie - jeśli ma być aktem prawdziwie ludzkim, czyli takim, któremu przysługuje cecha dobrowolności i racjonalności - musi wynikać $\mathrm{z}$ określonych racji do działania (reasons to action). Te racje zdobywamy właśnie na drodze rozumowania moralnego (implikatywnego, wewnętrznego, pierwszoosobowego), tak ja je opisali bohaterowie niniejszego artykułu. Dlatego zawsze musimy posiadać racje do działania: w każdej sytuacji, bez względu na standardowość lub wyjątkowość podjętej decyzji i działania. Rozumowanie praktyczne stanowi normę.

Prawdą jest jednak, że „struktury normalności” - o ile jeszcze jakieś pozostały w dominującej dziś kulturze płynnej nowoczesności - czasami mogą czynić zbędnymi prowadzenie namysłu w ramach wtórnego procesu rozumowania (ekplikatywnego, zewnętrznego, trzecioosobowego). Jeśli sami nie mamy wątpliwości co do podjętego działania (kryterium 
sumienia), ani nikt nie pyta nas o powody, racje naszego postępowania, to rozumowanie ekplikatywne staje się zbędne. I w tym znaczeniu rozumowanie etyczne możemy uznać - zgodnie z sugestią MacIntyre’a za coś ekstraordynaryjnego, niekoniecznego, wyjątkowego.

\section{Bibliografia}

Chmielewski A., MacIntyre a wspótczesna filozofia polityczna, w: A. MacIntyre, Czyja sprawiedliwość? Jaka racjonalność?, tłum. zbior., Warszawa 2007, s. 9-46.

Finnis J., A Grand Tour of Legal Theory, w: J. Finnis, Philosophy of Law. Collected Essays: Volume IV, New York 2011, s. 91-156.

Finnis J., Commensuration and Public Reason, w: J. Finnis, Reason in Action. Collected Essays: Volume I, New York 2011, s. 233-255.

Finnis J., Fundamentals of Ethics, Washington 1983.

Finnis J., Human Rights and Their Enforcement, w: J. Finnis, Human Rights and Common Good. Collected Essays: Volume III, New York 2011, s. 19-46.

Finnis J., Introduction, w: J. Finnis, Reason in Action. Collected Essays: Volume I, New York 2011, s. 1-15.

Finnis J., On Hart's Ways: Law as Reason and as Fact, w: J. Finnis, Philosophy of Law. Collected Essays: Volume IV, New York 2011, s. 230-256.

Finnis J., Practical Reason's Foundations, w: J. Finnis, Reason in Action. Collected Essays: Volume I, New York 2011, s. 19-40.

Finnis J., Practical Reasoning in Law: Some Clarifications, w: J. Finnis, Philosophy of Law. Collected Essays: Volume IV, New York 2011, s. 353-374.

Finnis J., Prawo naturalne i uprawnienia naturalne, tłum. K. Lossman, Warszawa 2002.

Finnis J., Grisez G., Boyle J., Practical Principles, Moral Truth, and Ultimate Ends, „American Journal of Jurisprudence" 32 (1987), s. 99-151.

Foot Ph., The Problem of Abortion and the Doctrine of the Double Effect, w: Ph. Foot, Virtues and Vices and Other Essays in Moral Philosophy, Oxford 2002, s. 19-32.

Gałecki S., Spór o sumienie. Źródła i konsekwencje etyki Johna Henry’ego Newmana, Kraków 2012.

MacIntyre A., Czyja sprawiedliwość? Jaka racjonalność?, tłum. zbior., Warszawa 2007.

MacIntyre A., Dziedzictwo cnoty. Studium z teorii moralności, tłum. A. Chmielewski, Warszawa 1996. 
MacIntyre A., Edyta Stein. Prolog filozoficzny 1913-1922, tłum. J. Guerrero van der Meijden, Kraków 2019.

MacIntyre A., Ethics in the Conflicts of Modernity. An Essay on Desire, Practical Reasoning, and Narrative, Cambridge 2016.

Newman J. H., Intellect, the Instrument of Religious Training, w: J. H. Newman, Sermons Preached on Various Occasions, London 1908, s. 1-14.

Newman J. H., Natura wiary w relacji do rozumu, w: J. H. Newman, Kazania uniwersyteckie. Piętnaście kazań wygłoszonych przed Uniwersytetem Oksfordzkim między 1826 a 1843 rokiem, tłum. P. Kostyło, Kraków 2000, s. 194-209.

Newman J. H., Przedmowa do wydania trzeciego, w: J. H. Newman, Kazania uniwersyteckie. Piętnaście kazań wygłoszonych przed Uniwersytetem Oksfordzkim między 1826 a 1843 rokiem, tłum. P. Kostyło, Kraków 2000, s. 19-23.

Newman J. H., Rozum implikatywny i rozum eksplikatywny, w: J. H. Newman, Kazania uniwersyteckie. Piętnaście kazań wygłoszonych przed Uniwersytetem Oksfordzkim między 1826 a 1843 rokiem, tłum. P. Kostyło, Kraków 2000, s. 234-256.

Reichenbach H., Trzy zadania epistemologii, tłum. W. Sady, „Studia Filozoficzne” 7-8 (1989) 284-285, s. 205-212.

Św. Ambroży z Mediolanu, Obowiązki duchownych, tłum. K. Abgarowicz, Warszawa 1967. Tomasz z Akwinu, Traktat o Bogu, tłum. G. Kurylewicz i inni, Kraków 1999.

\section{Abstrakt}

Czymś fundamentalnym dla etyki jest pytanie o to, w jaki sposób człowiek zdobywa swoją wiedzę o świecie moralnym, w tym przede wszystkim wiedzę na temat tego, co należy w danej sytuacji uczynić. Od czasów starożytnych ten obszar działalności człowieka nazywa się rozumowaniem praktycznym lub moralnym. Pod koniec ubiegłego wieku w świecie anglosaskim toczył się ciekawy spór o to, czy owo rozumowanie moralne ma charakter konieczny (stanowi warunek sine qua non każdego czynu), czy też stanowi coś wyjątkowego, dokonywanego przez podmiot tylko w wyjątkowo zawiłych sytuacjach moralnych. W swoim artykule staram się rozstrzygnąć ten spór, odwołując się do powszechnie przyjmowanego odróżnienia rozumowania prowadzącego do zdobycia racji do działania (rozumowanie implikatywne, pierwszoosobowy punkt widzenia) od rozumowania prowadzącego do wyrażenia tychże racji (rozumowanie eksplikatywne, trzecioosobowy punkt widzenia). 


\title{
Słowa kluczowe
}

A. MacIntyre, J. Finnis, J. H. Newman, rozumowanie praktyczne, etyka, metaetyka, racje działania

\begin{abstract}
Practical Reasoning - Rule or Exception?

One of the fundamental ethical questions is concerning the nature and method of the human acquisition of the moral knowledge - especially the knowledge about personal and actual obligations hic et nunc. Since ancient times this area of human activity has been called "practical" or "moral reasoning." At the end of twentieth century there have strated an interesting disputet whether this moral reasoning is necessary and regular (it is a sine qua non condition of every human act) or it is something rare and exceptional, carried out only in extremely difficult and untypical moral situations. In my paper, I'm trying to resolve this dispute by referring to the commonly accepted distinction between reasoning resulting in a "having a reason to act" (implicit reasoning, first-person point of view) and reasoning leading to "give a reason to act" (explicative reasoning, a third-person point of view).
\end{abstract}

\section{Keywords}

A. MacIntyre, J. Finnis, J. H. Newman, practical reasoning, ethics, meta-ethics, reasons to action 